RESEARCH ARTICLE

\title{
Quality attributes of snack made from maize substituted with groundnut
}

\author{
A.O. Dauda*, R.M.O. Kayode and K.O. Salami \\ Department of Home Economics and Food Science, University of Ilorin, Ilorin, Kwara State, Nigeria.
}

Received: 11/04/2019; Accepted: 20/012020

\begin{abstract}
Snacks made of maize are popular in Nigeria, but deficient in two essential amino acids (Tryptophan and lysine) and niacin. In this study, the quality attributes of maize snacks fortified with groundnut paste (10-40\%) of boiled and roasted groundnut were studied. The functional properties of the flour blends were analysed. Snacks were analysed for proximate, colour and sensory attributes. Results showed significant differences $(\mathrm{p}<0.05)$ in the proximate composition of the blends. Protein content increased with the substitution of groundnut paste (13.15 to $24.31 \%$ ), which could be responsible for the improved nutrition recorded in the snack samples produced. The ash, fat, and fibre contents also increased accordingly, with values ranging from $0.97-3.02 \%, 14.63-16.69 \%$, and $1.50-1.67 \%$ respectively, but the carbohydrate content decreased with increasing substitution of the maize flour with the groundnut paste. The water and oil absorption, as well as the swelling capacities significantly decreased when increased levels of groundnut paste were used. Sensory evaluation revealed that the snacks made with 10 and $20 \%$ roasted groundnut paste substitution were better accepted and therefore can be recommended for large scale production.
\end{abstract}

Keywords: Groundnut, Snacks, Maize, Proximate composition, Sensory qualities.

\section{INTRODUCTION}

Maize (Zea mays) is the major raw material used for the production of different snack foods. Though maize products are good for consumption, they should not be taken alone because they lack some essential micronutrients (Olanipekun, 2015). A maize snack known in Western Nigeria is Kokoro (Plate 1), one of the popular indigenous snacks, and snack consumption in the country is on the increase (Ayinde et al., 2012). The amino acids lacking in the maize can be complemented with pulses such as groundnut, soybean, and cowpea, which are better sources of lysine and tryptophan (Okaka, 2005). The comparatively low level of methionine and cysteine in legumes is to a large extent replaced by its higher proportions in most cereals. The valine and lysine content of soybean and those of groundnuts are high when compared with that of animal proteins (Okaka, 2005).

Groundnut (Arachis hypogaea), also known as peanut, earthnut, monkey-nut, manila-nut, and ground bean, are legumes exhibiting almost all the qualities of popular edible kernels such as pistachio, almonds etc., and they are the world's fourth most important source of edible vegetable oil, and third most important source of vegetable protein (Yvonne et al., 2007). Groundnuts are also rich in polyphenols and chief of the antioxidant group. They contain magnesium, folate, vitamin E, organic fibre; all of which helps to lessen the risk of cardiovascular disease (McDaniel et al., 2012). Due to its high nutritional value, it offers some health benefits, like prevention of chronic disease attributed to important soluble and insoluble fibre, slow digestive starch, prebiotic, oligosaccharide and phenolic compound. The 'slow starch digestion helps to regulate glycaemia; fibre helps on gastrointestinal function, while the phenolic compounds provide antioxidant properties (Cardador-martinez et al., 2002).

In most developing countries of the world including Nigeria, where diets are more of carbohydrate origin; the occurrence of protein-energy malnutrition is common especially among children (Ijarotimi and Keshinro, 2012). Groundnuts are of interest and handy, as they could provide high concentrations of essential amino acids for incorporation into high carbohydrate-based foods. This is because its products have the virtue of low cost and good nutritive value, and can be used for a variety of high protein beverages, desserts and similar products. It should also be noted that the fortification of snacks has evolved to enhance their nutritional quality (Neha and Ramash, 2012; Awolu et al., 2015).

As a result of the increase in the production and consumption of snacks, most especially maize-based ones by children and other age groups mostly due to urbanization, increase in the number of working class women mostly in Nigeria leading to drastic reduction in the act of cooking meals for the family and an increase in snack and outside food consumption, the need to improve nutritional content, add value and create varieties is imminent. This research work however, hopes to investigate the quality attributes of snacks made from maize fortified with groundnut, with both maize and groundnut properly screened of aflatoxin.

\section{MATERIALS AND METHODS}

High quality (in terms of yield and size, with number 30 Y 87 called pioneer seed) maize (Zea mays) and Nigerian high yielding round specie of groundnut (Arachis hypogaea) 
were purchased from a research institute in Ilorin metropolis of Kwara State, Nigeria. They have both been certified free of aflatoxin. Maize flour was obtained by the method of Atinuke and Aworh (2014). Whole maize grain was sorted to remove plant debris, stones, foreign matters etc. The sorted grains were then washed in water to remove dust and other tiny particles, drained and dried at $50^{\circ} \mathrm{C}$ in a hot air oven for 2-3 days before being milled into flour. Groundnut paste was obtained by the method of Ndidi et al. (2014) (for both boiled and roasted groundnut). Sorted groundnuts were sorted properly to obtain clean nuts, which were divided into two parts. One part was boiled in clean water $\left(100^{\circ} \mathrm{C}\right)$ in a seed to water ratio of $1: 10(\mathrm{w} / \mathrm{v})$. The boiled seeds were drained and mashed into a paste. The second part was roasted for one hour at a temperature of $300^{\circ} \mathrm{C}$, dehulled, cleaned and pulverised into a fine paste.
The blending ratios are as given in Table 1 .

\section{Production of Maize Snacks}

The method of Atinuke and Aworh (2014) was adopted with slight modification (see Figure 1). The process involved mixing the maize flour, sugar, and salt. Water $(100 \mathrm{~g}-\mathrm{v} / \mathrm{w})$ was boiled for 5 minutes and the blending of maize flour and groundnut paste was carried out by stepwise addition of a small quantity of water until a stretchy mixture was obtained. Maize flour was then added to thicken the mixture for convenient kneading. The dough was then cooled to a temperature of about $40^{\circ} \mathrm{C}$ for ease of hand kneading for about 5 minutes. The dough was then rolled on a flat table to get the desired shape. These were then fried in vegetable oil at $150-170^{\circ} \mathrm{C}$ for 5 minutes. The snacks produced were drained of excess oil and left to cool.

Table 1: Blends of Maize Flour and Groundnut Paste for the Production of snacks of different blends of maize and groundnut.

\begin{tabular}{cccc}
\hline Samples & Maize flour \% & Roasted groundnut paste (\%) & Boiled groundnut paste (\%) \\
\hline AA & 100 & - & - \\
BB & 90 & 10 & - \\
CC & 80 & 20 & - \\
DD & 70 & 30 & - \\
EE & 60 & 40 & - \\
FF & 90 & - & 10 \\
GG & 80 & - & 20 \\
HH & 70 & - & 30 \\
II & 60 & - & 40 \\
\hline
\end{tabular}

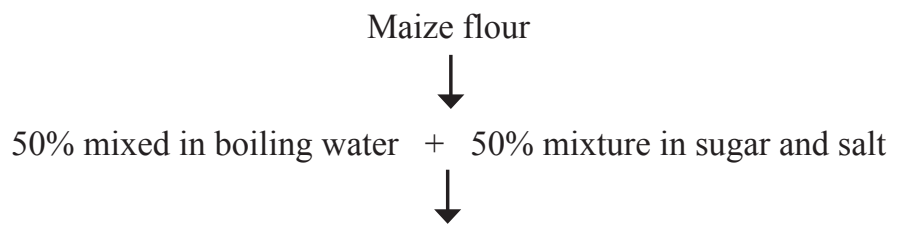

Addition of groundnut paste

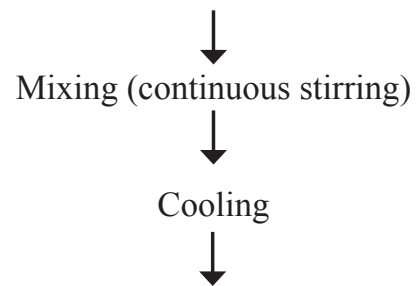

Kneading

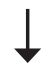

Rolling into shapes

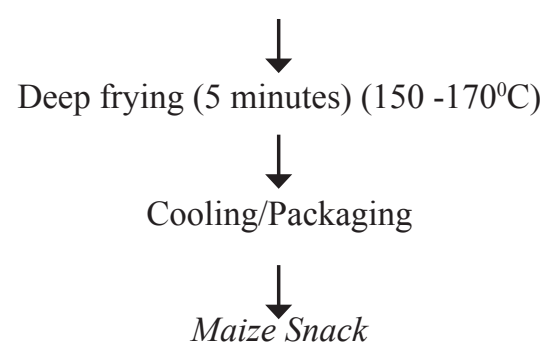

Figure 1: Flow Chart for the Production of snacks of different blends of maize and groundnut. 


\section{Proximate Analysis}

The proximate composition of the snack samples was done by following the procedure described by the Association of Official Analytical Chemists (AOAC, 2002). The samples were analysed for moisture, ash, crude fibre, crude protein, and crude fat, whereas carbohydrate was calculated by the difference. Briefly, $2 \mathrm{~g}$ of the sample was weighed and dried to constant weight in an oven (at $105^{\circ} \mathrm{C}$ for 5 hours), cooled, and percentage moisture determined. $2 \mathrm{~g}$ of the samples was equally weighed into the kjeldahl flask for protein determination. Digestion and distillation processes took place before titrating the outcome to determine the percentage crude protein content. For percentage ash content, $2 \mathrm{~g}$ of the sample was transferred into a muffle furnace adjusted to $550^{\circ} \mathrm{C}$ for 4 hours. The soxhlet extraction method was used for the percentage fat content determination, where $2 \mathrm{~g}$ of the sample was weighed into the extraction thimble. Percentage crude fibre was determined by measuring $2 \mathrm{~g}$ of the sample into a fibre flask and 100 $\mathrm{ml}$ of $0.255 \mathrm{~N} \mathrm{H}_{2} \mathrm{SO}_{4}$ was added. The mixture was boiled for 30 minutes with a heating mantle, cooled and filtered. The filter paper with the residue was oven dried at $105^{\circ} \mathrm{C}$ for 3 hours before determination, while the percentage carbohydrate content was determined by difference.

\section{Functional Properties of the Flour Blends}

Water and oil absorption capacities were determined according to the method of Niba et al. (2001). Flour sample (1g) was suspended in $5 \mathrm{ml}$ of water in a centrifugal tube. The slurry formed was shaken for about 60 seconds and centrifuged at 3000rpm for 10 minutes. The supernatant was decanted and discarded, with the adhering drops used for the determination of water absorption capacity $(\mathrm{g} / \mathrm{g})$. The same procedure was adopted for the oil absorption capacity, but in this case, the $1 \mathrm{~g}$ of the flour sample was suspended in $5 \mathrm{ml}$ of oil and not water. Swelling Capacity however, was determined using the method of Alfonso et al. (1998). The difference between the volume before and after soaking the flour sample in water for 18 hours was used.

\section{Determination of Colour of the Snacks Produced}

The colour attributes (Hunter L, a, and b values) of the Maize flour and groundnut paste were obtained with a Rapid Visco Analyser and measured using a Minolta portable chroma-meter. The hunter lab colour coordinates system $\mathrm{L}^{*} \mathrm{a}^{*}$ and $\mathrm{b}^{*}$ values were recorded and the brown index was calculated. Each sample was measured at four spots using standard $L^{*}=53.44, a^{*}=-24.94, b^{*}=12.94$ values. Whiteness index was calculated according to $\mathrm{Hsu}$ et al. (2003) and brown index by Babajide et al. (2006). Where; $\mathrm{L}$, $\mathrm{a}$, and $\mathrm{b}$ were Hunter $\mathrm{L}^{*}=$ Whiteness, $\mathrm{a}^{*}=$ Redness and $\mathrm{b}^{*}=$ yellowness values.

\section{Sensory Evaluation}

Consumer acceptability of the snacks made from 100\% maize flour substituted with 10, 20, 30 and $40 \%$ of roasted and boiled groundnut paste respectively, was determined by a panel of thirty five (35), who are untrained but regular consumers of maize snacks. They comprised twenty female and fifteen male of between 15 and 50 years of age. Though they are not professional assessors, but very familiar with maize snacks, consume regularly and close to local producers. The panelists were supplied with a form and asked to score the samples using 9-point Hedonic scale for taste, appearance, crunchiness, aroma and overall acceptability. All the results were subjected to statistical analysis using SPSS 15. The scores were ranked and analyzed using ANOVA.

\section{RESULTS AND DISCUSSION}

\section{Proximate composition}

The results of the proximate composition of the maize snack samples are as shown in Table 2. It was seen that the crude protein content of the samples increased with an increase in the quantities of groundnut paste as expected. The result obtained correlates with the requirement of FAO (2008) that protein content should be at least $20 \%$ in any food. Sample AA (100\% Maize flour), which was the control sample, had the lowest protein content of $13.15 \pm 0.06 \%$, while Sample

Table 2: Proximate Composition of the snacks of different blends of maize and groundnut.

\begin{tabular}{ccccccc}
\hline Samples & Moisture (\%) & Fat (\%) & Ash (\%) & Protein (\%) & Fibre (\%) & Carbohydrate (\%) \\
\hline AA & $7.13^{\mathrm{f}} \pm 0.19$ & $14.63^{\mathrm{d}} \pm 0.38$ & $0.97^{\mathrm{e}} \pm 0.03$ & $13.15^{\mathrm{f}} \pm 0.06$ & $1.50^{\mathrm{a}} \pm 0.00$ & $62.61^{\mathrm{a}} \pm 0.26$ \\
BB & $8.01^{\mathrm{e}} \pm 0.02$ & $15.42^{\mathrm{b}} \pm 0.03$ & $1.40^{\mathrm{d}} \pm 0.06$ & $15.64^{\mathrm{d}} \pm 0.19$ & $1.50^{\mathrm{a}} \pm 0.00$ & $58.02^{\mathrm{c}} \pm 0.20$ \\
CC & $10.00^{\mathrm{c}} \pm 0.50$ & $16.14^{\mathrm{a}} \pm 0.02$ & $2.00^{\mathrm{c}} \pm 0.01$ & $16.83^{\mathrm{c}} \pm 0.22$ & $1.50^{\mathrm{a}} \pm 0.00$ & $53.54^{\mathrm{e}} \pm 0.65$ \\
DD & $11.20^{\mathrm{b}} \pm 1.13$ & $16.38^{\mathrm{a}} \pm 0.03$ & $2.45^{\mathrm{b}} \pm 0.08$ & $18.91^{\mathrm{b}} \pm 0.30$ & $1.60^{\mathrm{a}} \pm 0.17$ & $49.33^{\mathrm{g}} \pm 1.05$ \\
EE & $13.50^{\mathrm{a}} \pm 1.32$ & $16.69^{\mathrm{a}} \pm 0.08$ & $2.80^{\mathrm{a}} \pm 0.26$ & $24.31^{\mathrm{a}} \pm 0.07$ & $1.57^{\mathrm{a}} \pm 0.40$ & $41.14^{\mathrm{h}} \pm 1.45$ \\
FF & $8.04^{\mathrm{e}} \pm 0.04$ & $15.00^{\mathrm{c}} \pm 0.03$ & $1.50^{\mathrm{d}} \pm 0.02$ & $14.14^{\mathrm{e}} \pm 0.14$ & $1.33^{\mathrm{a}} \pm 0.58$ & $59.98^{\mathrm{b}} \pm 0.53$ \\
GG & $8.75^{\mathrm{d}} \pm 0.25$ & $15.07^{\mathrm{c}} \pm 0.01$ & $1.99^{\mathrm{c}} \pm 0.01$ & $14.70^{\mathrm{e}} \pm 0.14$ & $1.50^{\mathrm{a}} \pm 0.00$ & $57.99^{\mathrm{c}} \pm 0.34$ \\
HH & $9.83^{\mathrm{c}} \pm 0.53$ & $15.17^{\mathrm{b}} \pm 0.01$ & $2.77^{\mathrm{a}} \pm 0.23$ & $15.24^{\mathrm{d}} \pm 0.08$ & $1.67^{\mathrm{a}} \pm 0.29$ & $55.32^{\mathrm{d}} \pm 0.67$ \\
II & $12.21^{\mathrm{b}} \pm 0.26$ & $15.23^{\mathrm{b}} \pm 0.02$ & $3.02^{\mathrm{a}} \pm 0.02$ & $16.21^{\mathrm{c}} \pm 0.02$ & $1.67^{\mathrm{a}} \pm 0.29$ & $51.66^{\mathrm{f}} \pm 0.55$ \\
\hline
\end{tabular}

Mean \pm SD of three replicates. Values in the same column with different superscript are significantly different $(\mathrm{p}<0.05)$

Maize: roasted Groundnut Ratio- AA-(100\%Maize), BB-(90:10), CC-(80:20), DD-(70:30), EE-(60:40). Maize: boiled Groundnut Ratio-FF-(90:10), GG-(80:20), HH-(70:30), II-(60:40) 
EE ( $60 \%$ maize flour and $40 \%$ roasted groundnut paste) had the highest protein content of $24.31 \pm 0.07 \%$. Samples with the boiled groundnut paste were higher than the control, but less than those with the roasted groundnut, with protein contents of $15.643 \pm 0.19 \%$ to $24.31 \pm 0.07 \%$, as against those with boiled groundnut paste $(14.14 \pm 0.14 \%$ to $16.21 \pm$ $0.02 \%)$. The reduced value of protein content recorded for samples with boiled groundnut paste could be due to losses that may have resulted from leaching of the nutrient during the boiling process. Hugo (2000) has stated that nutrient loss, especially protein, might be due to leaching of soluble nitrogen into solution during boiling. The protein content recorded for samples with roasted groundnut compared favourably with that reported by Uzor-Peters et al. (2008), where 11.82 and $14 \%$ were reported for snack made from $90 \%$ and $10 \%$ maize flour and defatted soybean or groundnut cake and 28.46 to $35.10 \%$ for blend of $10 \%$ and $90 \%$ maize flour and defatted soybean or groundnut cake obtained from a feed mill. It was reported then that the use of defatted soybean and groundnut cake should necessarily increase the concentration of protein available.

Sample AA (100\% Maize flour) had the lowest moisture content $(7.13 \pm 0.19 \%)$, whereas the moisture content of the other samples increased with increasing addition of the groundnut paste. Sample BB (90\% Maize flour, 10\% Roasted groundnut paste) had a moisture content of $8.01 \pm$ $0.02 \%$, whereas Sample FF (90\% Maize flour, 10\% Boiled groundnut paste) had a moisture content of $8.04 \pm 0.04 \%$. This could imply a fairly stable shelf life for the product if properly packaged in line with the production conditions. Ewulo et al., 2016 and Atinuke and Aworh (2014) reported that oil in foods normally reduces the moisture, which could have been the reason for the samples with boiled groundnut to have a higher moisture content than those with roasted groundnut samples.

A similar pattern to that of protein content was shown by the fat content. The increase in the fat and protein contents could be due to the blending of roasted and boiled groundnut with the product mixture, and this may have affected the oil absorption capacity of the dough and may have resulted in the high-fat content in those blends with higher proportions of groundnut. Sample AA (100\% Maize flour) had the lowest fat content $(14.63 \pm 0.38 \%)$, while sample EE with $40 \%$ roasted groundnut paste had the highest $(16.69 \pm 0.08 \%)$ when compared to ' $15.23 \pm 0.02 \%$ ' recorded for sample II with $40 \%$ boiled groundnut paste. It could also be stated that the fat content recorded for samples with boiled groundnut was comparable to that reported by Ayinde et al. (2012) for a snack made from maize blended with beniseed cake (14.70-15.85\%). It was even far higher than that reported by Adepoju et al. (2012) and Agoyero et al. (2011) respectively who both reported between 1.91 and $3.90 \%$, though expected.

Crude fibre is known to aid the digestive system of humans. There was no significant difference $(p>0.05)$ in the crude fibre, with values ranging from $1.33 \pm 0.58$ to $1.67 \pm 0.29 \%$. Sample II with $40 \%$ boiled groundnut paste had the highest crude fibre $(1.67 \pm 0.29 \%)$, while the control (100\% maize flour) had $1.5 \%$. The samples from the boiled groundnut had slightly higher crude fibre content than samples with roasted groundnuts, but the crispness of samples with roasted groundnut paste reduced as the quantity of roasted groundnut paste increased, probably due to the oil content.

The ash content showed a significant difference (at $\mathrm{p}<0.05$ ), with values ranging from $0.97 \pm 0.03 \%$ to $3.02 \pm 0.02 \%$. Increasing the amount of groundnut paste increased the ash content, with 100\% Maize flour having the lowest value $(0.97 \pm 0.03 \%)$ and Sample II with $40 \%$ boiled groundnut paste having the highest $(3.02 \pm 0.02 \%)$. The increase in ash content was an indication of an increase in the mineral content of the snack, which was similar to the report of some other researchers such as that of Yarkwan and Uvir, 2015. Samples with roasted groundnut paste had ash content in the range (1.40 to $2.80 \%)$, and were lower than samples with boiled groundnuts (1.50 to $3.02 \%)$, but higher than that reported for the control sample.

There was a significant difference $(\mathrm{p}<0.05)$ among the samples for the carbohydrate content. The values ranged from $41.14 \pm 1.45 \%$ to $62.61 \pm 0.26 \%$. The decrease in carbohydrate with the incorporation of groundnut paste was expected as Sample EE (60\% maize flour and 40\% roasted groundnut paste) had the lowest carbohydrate content. Though, the quantity of carbohydrate in the samples was decreasing, as the quantity of protein and fat were increasing, the study affirmed that higher protein contents give lower carbohydrate contents. Roasted groundnut paste samples with higher protein contents than that with boiled groundnut paste had lower carbohydrate contents.

\section{Functional Properties of the Flour used for the Snack Production}

The results obtained are as shown in Table 3 . There were significant differences $(\mathrm{p}<0.05)$ in the functional properties measured. The water absorption capacity was highest in Sample AA (100\% maize flour) with $1.83 \pm 0.01 \mathrm{~g} / \mathrm{g}$ and decreased subsequently with increasing quantities of added roasted groundnut paste $(1.34 \pm 0.06 \mathrm{~g} / \mathrm{g}, 1.28 \pm 0.07 \mathrm{~g} / \mathrm{g}$, $1.23 \pm 0.04 \mathrm{~g} / \mathrm{g}, 1.14 \pm 0.04 \mathrm{~g} / \mathrm{g}$ ) for samples BB, CC, DD, EE respectively, but increased with increasing quantities of the added boiled groundnut paste $(1.31 \pm 0.04 \mathrm{~g} / \mathrm{g}, 1.36 \pm 0.08$ $\mathrm{g} / \mathrm{g}, 1.39 \pm 0.16 \mathrm{~g} / \mathrm{g}, 1.56 \pm 0.04 \mathrm{~g} / \mathrm{g}$ ) respectively for samples $\mathrm{FF}, \mathrm{GG}, \mathrm{HH}$, and II. The reduction in the value of the water absorption capacity of the samples with roasted groundnut paste could be attributed to its oily nature that could have made them viscous when processed into a paste. The moist nature noticed in the samples with boiled groundnut paste could have caused the absorption of less water during processing. The reduction in the water absorption capacity of the samples with the incorporation of roasted and boiled groundnut could also be due to the decrease in the quantity of gluten, as a result of the substitution, leading to less water retention (Sirichokworrakit et al., 2015).

The oil absorption capacity of any food is hinged mainly on its capacity to entrap oil by a complex capillary attraction process; a good characteristic since oil acts as a flavour enhancer, good trait and improves mouth feel (Khattab and Arntfield, 2009). The oil absorption capacity 
Table 3: Functional Properties of the Composite Flour used for snacks of different blends of maize and groundnut.

\begin{tabular}{cccc}
\hline Samples & Water absorption Capacity $(\mathbf{g} / \mathbf{g})$ & Oil Absorption capacity $(\mathbf{g} / \mathbf{g})$ & Swelling Capacity \\
\hline AA & $1.830^{\mathrm{a}} \pm 0.01$ & $2.210^{\mathrm{a}} \pm 0.14$ & $4.290^{\mathrm{a}} \pm 0.02$ \\
BB & $1.340^{\mathrm{c}} \pm 0.06$ & $1.980^{\mathrm{b}} \pm 0.03$ & $4.270^{\mathrm{a}} \pm 0.02$ \\
CC & $1.275^{\mathrm{d}} \pm 0.07$ & $1.905^{\mathrm{bc}} \pm 0.01$ & $4.245^{\mathrm{a}} \pm 0.01$ \\
DD & $1.230^{\mathrm{d}} \pm 0.04$ & $1.760^{\mathrm{c}} \pm 0.04$ & $4.240^{\mathrm{a}} \pm 0.01$ \\
EE & $1.140^{\mathrm{e}} \pm 0.04$ & $1.620^{\mathrm{d}} \pm 0.02$ & $4.230^{\mathrm{a}} \pm 0.01$ \\
FF & $1.305^{\mathrm{c}} \pm 0.04$ & $1.910^{\mathrm{b}} \pm 0.02$ & $4.260^{\mathrm{a}} \pm 0.01$ \\
GG & $1.360^{\mathrm{c}} \pm 0.08$ & $1.860^{\mathrm{bc}} \pm 0.00$ & $4.245^{\mathrm{a}} \pm 0.01$ \\
HH & $1.390^{\mathrm{c}} \pm 0.16$ & $1.650^{\mathrm{cd}} \pm 0.02$ & $4.205^{\mathrm{a}} \pm 0.01$ \\
II & $1.560^{\mathrm{b}} \pm 0.04$ & $1.560^{\mathrm{e}} \pm 0.04$ & $4.190^{\mathrm{a}} \pm 0.01$ \\
\hline
\end{tabular}

Mean \pm SD of three replicates Values in the same column with different superscript are significantly different $(\mathrm{P}<0.05)$

Maize: roasted Groundnut Ratio- AA-(100\%Maize), BB-(90:10), CC-(80:20), DD-(70:30), EE-(60:40). Maize: boiled Groundnut Ratio-FF-(90:10), GG-(80:20), HH-(70:30), II-(60:40)

Table 4: Colour determination of the snacks of different blends of maize and groundnut.

\begin{tabular}{cccc}
\hline Samples & $\mathbf{L}^{*}$ & $\mathbf{a}^{*}$ & $\mathbf{b}^{*}$ \\
\hline AA & $34.43^{\mathrm{d}} \pm 0.00$ & $8.17^{\mathrm{a}} \pm 2.03$ & $12.01^{\mathrm{b}} \pm 2.09$ \\
BB & $37.52^{\mathrm{b}} \pm 0.78$ & $6.00^{\mathrm{b}} \pm 0.86$ & $14.19^{\mathrm{a}} \pm 0.18$ \\
CC & $37.10^{\mathrm{b}} \pm 2.31$ & $7.77^{\mathrm{a}} \pm 0.77$ & $14.37^{\mathrm{a}} \pm 1.70$ \\
DD & $29.24^{\mathrm{e}} \pm 1.64$ & $4.70^{\mathrm{c}} \pm 1.53$ & $8.16^{\mathrm{c}} \pm 1.42$ \\
EE & $34.85^{\mathrm{d}} \pm 2.40$ & $5.76^{\mathrm{b}} \pm 1.17$ & $10.93^{\mathrm{b}} \pm 2.0$ \\
FF & $36.05^{\mathrm{c}} \pm 0.63$ & $4.18^{\mathrm{d}} \pm 0.49$ & $10.81^{\mathrm{b}} \pm 0.68$ \\
GG & $34.15^{\mathrm{d}} \pm 1.67$ & $5.21^{\mathrm{bc}} \pm 0.57$ & $10.75^{\mathrm{b}} \pm 1.39$ \\
HH & $34.92^{\mathrm{d}} \pm 6.41$ & $6.20^{\mathrm{b}} \pm 0.01$ & $11.38^{\mathrm{b}} \pm 3.26$ \\
II & $39.01^{\mathrm{a}} \pm 3.83$ & $5.79^{\mathrm{b}} \pm 2.42$ & $12.72^{\mathrm{a}} \pm 1.07$ \\
\hline
\end{tabular}

Mean \pm SD of three replicates Means in the same row with different superscripts are significantly different $(p<0.05)$. $L^{*}, a^{*}, b^{*}$ means lightness, yellowness and redness respectively .

Maize: roasted Groundnut Ratio- AA-(100\%Maize), BB-(90:10), CC-(80:20), DD-(70:30), EE-(60:40). Maize: boiled Groundnut Ratio-FF-(90:10), GG-(80:20), HH-(70:30), II-(60:40)

showed significant differences (at $\mathrm{p}<0.05$ ) among the samples, showing a range of $1.56 \pm 0.04 \mathrm{~g} / \mathrm{g}$ to $2.21 \pm 0.14$ $\mathrm{g} / \mathrm{g}$. The oil absorption capacity was lowest in sample II (60\% maize flour and $40 \%$ boiled groundnut paste), which was lower than that recorded for samples with roasted groundnut, but higher than that of the control Sample AA (100\% maize flour). This result compared favourably with the report of Ayinde et al. (2012), where it was reported that beniseed added increased the oil content. The fat in the groundnut incorporated could have reduced the oil absorption capacities of the samples with groundnut paste.

The swelling capacity is a function of the product rising or expanding when interacting with water, and according to Finney 1994, swelling capacity influences the temperature at which products form a gel in maize flour. Though, there were no significant differences $(p>0.05)$ in the values, they decreased with increasing quantities of groundnut paste and a decreasing quantity of maize flour. Sample AA (control) had the highest swelling capacity of $4.29 \pm 0.02$, while sample II had the lowest $(4.19 \pm 0.01)$. The samples with roasted groundnut paste (BB, CC, DD and EE) have higher swelling capacity than samples with the boiled groundnut paste.

\section{Colour Determination and Sensory Evaluation}

Colour is considered as one of the most important quality parameters of deep fat fried snacks. As the quantity of groundnut paste increases, the lightness parameter of the fried product reduced, whereas the redness and yellowness parameters were unstable (Table 4). This implies that the addition of groundnut paste to the snacks affected its colour as shown with the fluctuating values recorded, especially for the yellowness and redness of the snack. The snack made from the blend of $90: 10 \%$ of the maize-roasted groundnut blend was the most desired by the consumers as seen from the significant differences in the score for appearance in the sensory evaluation (Table 5).

The differences in the colour and crunchiness of the samples in the sensory evaluation may be due to the proportion of the groundnut added to the product (Mempha et al., 2007; Yam and Papadakis, 2004). Samples made from maize flour blended with $10 \%$ and $20 \%$ of roasted 
Table 5: Mean Sensory score of snacks of different blends of maize and groundnut.

\begin{tabular}{cccccc}
\hline Samples & Appearance & Crunchiness & Aroma & Taste & General acceptability \\
\hline AA & $7.05^{\mathrm{a}} \pm 0.83$ & $7.20^{\mathrm{a}} \pm 1.01$ & $6.55^{\mathrm{b}} \pm 1.05$ & $6.85^{\mathrm{b}} \pm 1.27$ & $7.20^{\mathrm{a}} \pm 0.95$ \\
BB & $7.20^{\mathrm{a}} \pm 0.95$ & $7.30^{\mathrm{a}} \pm 1.08$ & $7.15^{\mathrm{a}} \pm 0.99$ & $7.70^{\mathrm{a}} \pm 0.98$ & $7.50^{\mathrm{a}} \pm 1.10$ \\
CC & $6.70^{\mathrm{a}} \pm 1.30$ & $6.80^{\mathrm{a}} \pm 1.32$ & $7.15^{\mathrm{a}} \pm 0.99$ & $7.65^{\mathrm{a}} \pm 1.23$ & $7.60^{\mathrm{a}} \pm 1.04$ \\
DD & $5.10^{\mathrm{c}} \pm 1.62$ & $4.30^{\mathrm{c}} \pm 1.81$ & $7.25^{\mathrm{a}} \pm 1.41$ & $7.20^{\mathrm{ab}} \pm 1.64$ & $5.40^{\mathrm{d}} \pm 2.16$ \\
EE & $4.20^{\mathrm{d}} \pm 1.94$ & $3.20^{\mathrm{d}} \pm 1.58$ & $7.35^{\mathrm{a}} \pm 0.59$ & $7.55^{\mathrm{a}} \pm 1.19$ & $4.20^{\mathrm{e}} \pm 1.67$ \\
FF & $6.35^{\mathrm{b}} \pm 1.23$ & $6.85^{\mathrm{a}} \pm 0.99$ & $4.70^{\mathrm{d}} \pm 1.46$ & $6.15^{\mathrm{d}} \pm 1.50$ & $6.50^{\mathrm{b}} \pm 1.67$ \\
GG & $6.10^{\mathrm{b}} \pm 1.33$ & $6.25^{\mathrm{b}} \pm 1.21$ & $5.30^{\mathrm{c}} \pm 0.87$ & $6.70^{\mathrm{b}} \pm 1.08$ & $6.40^{\mathrm{b}} \pm 0.82$ \\
HH & $5.85^{\mathrm{bc}} \pm 1.27$ & $6.35^{\mathrm{b}} \pm 0.93$ & $5.20^{\mathrm{c}} \pm 0.62$ & $6.35^{\mathrm{c}} \pm 0.88$ & $5.65^{\mathrm{d}} \pm 1.22$ \\
II & $5.95^{\mathrm{bc}} \pm 1.23$ & $6.15^{\mathrm{b}} \pm 0.88$ & $5.40^{\mathrm{c}} \pm 1.19$ & $6.30^{\mathrm{c}} \pm 1.26$ & $6.00^{\mathrm{c}} \pm 1.34$ \\
\hline
\end{tabular}

Mean \pm SD of three replicates. Means in the same row with different superscripts are significantly different $(\mathrm{p}<0.05)$.

Maize: roasted Groundnut Ratio- AA-(100\%Maize), BB-(90:10), CC-(80:20), DD-(70:30), EE-(60:40). Maize: boiled Groundnut Ratio-FF-(90:10), GG-(80:20), HH-(70:30), II-(60:40)

groundnut paste were the most preferred by the panelists. The overall acceptance of the snacks could have been influenced by the crunchiness, appearance, and taste. Score 9 was most preferred, while score 1, least preferred in the sensory attributes. It could be seen that Sample EE (60:40) of roasted groundnut paste had a sensory score of 7.35 on the average for aroma (highest), though not significantly different $(\mathrm{p}>0.05)$ from samples BB, CC and DD, while sample FF (90:10) of boiled groundnut paste had the least acceptance. It could be seen from the score that roasting improved the aroma and taste of the snack samples. The results indicated that an increase in groundnut paste causes an increase in the score attributes in terms of the aroma. The taste of the snacks with roasted groundnut received a higher rating than the ones with boiled groundnut. It could however be said that roasting might have improved the characteristic taste of the snacks produced. Overall, snack samples with roasted groundnut paste received a better rating in terms of appearance, crunchiness, aroma and taste. On the general acceptability, the control and samples with $10 \%$ and $20 \%$ roasted groundnut paste were most preferred.

\section{CONCLUSIONS}

Combining maize flour with groundnut paste showed varied physical and functional properties depending on whether the added groundnuts were roasted or boiled. The type of maize flour also influenced some of the functional behaviour of the samples. The addition of roasted groundnut paste to the maize flour made it more oily, while boiled groundnut paste made it less oily. It could therefore, be said that acceptable snacks can be made from different maizegroundnut blends, which could bring up improved products with better nutritional quality than that from plain maize flour. The snack would increase protein content, which could be an ideal source of dietary protein.

The results of this study show that blends of $90 \%$ maize flour and 10\% roasted groundnut paste, and $80 \%$ maize flour and $20 \%$ roasted groundnut paste, are suitable for the production of maize snacks, known as Kokoro.

\section{DECLARATION OF CONFLICT OF INTEREST}

The authors declare that there is no conflict of interest.

\section{REFERENCES}

Adepoju, O.T., Sunday, B.E. and Folaranmi, O.A. (2012). Nutrient composition and contribution of plantain (Musa paradisiacea) products to dietary diversity of Nigerian consumers. African Journal of Biotechnology, 11(71):13601-13605.

Agoreyo, B.O., Akpiroroh, O.O., Orukpe, A., Osaweren, O.R. and Owabor, C.N. (2011). The effect of various drying methods on the nutritional composition of Musa paradisiaca, Dioscorea rotundata and Colocasia esculenta. Asian J Biochem, 6(6): 458-464.

Clemente, A., Sánchez-Vioque, R., Vioque, J., Bautista, J. and Millán, F. (1998). Effect of processing on water absorption and softening kinetics in chickpea (Cicer arietinumL) seeds. Journal of the Science of Food and Agriculture, 78(2): 169-174.

AOAC, 2002. Official Method of Analysis of the Association of Official Analytical Chemists 17th Edition.

Atinuke, O.I and Aworh, O.C. (2014). Optimization of some processing conditions for Kokoro production using Response Surface Methodology, Agric Eng Int: CIGR Journal, 16(2): 187-195.

Awolu, O.O., Oluwaferanmi, P.M., Fafowora, O.I and Oseyemi, G.F. (2015). Optimization of the extrusion process for the production of ready-to-eat snack from rice, cassava and kersting's groundnut composite flour. LWT-Food Science and Technology. 64(1): 18-24.

Ayinde, F.A., Bolaji, O.T., Abdul-Salaam, R.B. and Osidipe O. (2012). Functional properties and quality evaluation of "kokoro" blended with beniseed cake Sesame indicum, African Journal of Food Science, 6(5): 117123.

Babajide, J.M., Oyewole, O.B., Henshaw, F.O., Babajide, S.O. and Olasantan, F.O. (2006). Effect of local preservatives on quality of traditional dry yam slices "Gbodo" and its products. World Journal of Agricultural Sciences. 2(3): 267-273. 
Cardador-Martinez, A., Loarca-Pina, G. and Oomah, B.D. (2002). Antioxidant activity in common beans (Phaseolus vulgar L.). Journal of Agriculture and Food Chemistry, 50(24): 75-80.

Ewulo, T.O., Oluwalana, I.B., Ewulo, B.S. and Awolu, O. (2016). Enrichment of traditional maize snack (kokoro) with moringa oleifera leaf and soybean. African Journal of Food Science, 11(5):249-254.

FAO, 2008. Food and Agricultural Organization Production year book.

Finney, K.F. (1994). Contribution of individual chemical constituents to the functional (bread making) properties of wheat in cereal. Nutrition for the world million people of Minnesota. American Association of Cereal Chemist Inc.

Hsu, C.L., Chen, W., Weng, Y.M. and Tseng, C.Y. (2003). Chemical composition, physical properties, and antioxidant activities of yam flours as affected by different drying methods. Food Chemistry. 83(1): 8592.

Hugo, C. (2000). Quality protein maize: Improved nutrition and livelihood for the poor. Maize Res. Highlights, 3(2): 0999-1008.

Ijarotimi, O.S. and Keshinro, A.A. (2012). Formulation and nutritional quality of infant formular produced from germinated popcorn, Bambara groundnut, and African locust bean flour. Journal of Microbiological Biotechnology and Food Science. 1(6): 1358-1388.

Khattab, R. and Arnfield, S. (2009). Functional Properties of raw and processed canola meal. Food Science and Technology. 42(6): 1119-1124.

McDaniel, Kristin,A., White, B.L., Dean, L.L., Sanders, T.H. and Davis, J.P. (2012). Compositional and mechanical properties of peanut roasted to equivalent colours using different time/temperature combinations. Publications from USDA-ARS/UNL Faculty. Paper 1114.http// digitalcommons.unl.edu/usdaarsfacpub/1114.

Mempha, D.H., Luayt, D. and Niraojigoh, S.U. (2007). Chemical, Composition, Functional Composition and Baking properties of Wheat plantain composite flour. Afr. J. Food Agric. Nutri, Dev. 7(1):1-22.

Ndidi, U.S., Ndidi, C.U., Aimola, I.A., Bassa, O.Y., Mankilik, M. and Adamu, Z. (2014).

Effects of processing (boiling and roasting) on the nutritional and antinutritional properties of Bambara groundnuts (Vigna subterranea [L.] Verdc.) from Southern Kaduna, Nigeria. Journal of Food Processing, 2014. http:// dx.doi.org/10.1155/2014/472129

Neha, M. and Ramesh, C. (2012). Development of functional biscuit from soy flour and rice bran. International Journal Agriculture Food Science 2: 14-20.

Niba, L.L., Bokanga, M.M., Jackson, F.L., Schlimme, D.S. and Li, B.W. (2002). Physicochemical properties and starch granular characteristics of flour from various Manihot esculenta (cassava) genotypes. Journal of food science, 67(5): 1701-1705.

Okaka, J.C. (2005). Basic Processing of grain cereals and legumes In: Handling, Storage and processing of plant food; OCJ Academic Publishers, Enugu, Nigeria. Pp.30-60.

Olanipekun, O.T., Olapade, O.A., Suleiman, P. and Ojo,
S.O. (2015). Nutrient and sensory analysis of abari made from composite mixture of kidney bean flour and maize flour. Nigeria Food Journal, 4(2), pp.19-23.

Sirichokworrakit, S., Phetkhut, J. and Khommoon, A. (2015). Effect of partial substitution of wheat flour with riceberry flour on quality of noodles. Procedia-Social and Behavioral Sciences, 197, pp.1006-1012.

Uzor-Peters, P.I., Arisa, N.U., Lawrence, C.O., Osondu, N.S. and Adelaja, A. (2008). Effect of partially defatted soybeans or groundnut cake flours on proximate and sensory characteristics of kokoro. African Journal of Food Science, 2(8): 098-101.

Yarkwan, B. and Uvir, R.H. (2015). Effects of drying methods on the nutritional composition of unripe plantain flour. Food Science and Quality Management, 41, pp.5-10.

Yam, K.L. and Papadakis, S.E. (2004). A simple digital imaging method for measuring and analyzing color of food surfaces. Journal of food Engineering, 61(1), pp.137-142.

Yvonne, C., Lloyd, W., Bernhard, V. and Martha, V. (2007). Changes in the phytochemical composition and profile of raw, boiled and roasted peanuts. Journal of Agriculture and Food Chemistry, 55(22): 9266-9273. 